See discussions, stats, and author profiles for this publication at: https://www.researchgate.net/publication/243973358

\title{
Comparative analysis of managerial values in the USA and China
}

Article in Journal of Technology Management in China · October 2007

DOI: 10.1108/17468770710825151

CITATIONS

18

2 authors:

Ravi Chinta

39 PUBLICATIONS 135 CITATIONS

SEE PROFILE
READS

155

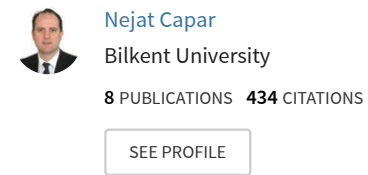




\section{JTMC \\ 2,3}

212

\section{Comparative analysis of managerial values in the USA and China}

\author{
Ravi Chinta
}

Strategy and Entrepreneurship College of Business Administration, Pennsylvania State University, Middletown, Pennsylvania, USA, and

Nejat Capar

Department of Management, Bilkent University, Ankara, Turkey

\begin{abstract}
Purpose - China, one of the fastest growing economies in the world, has become a major trading partner with the USA. However, trading with Chinese involves major cultural barriers. The Chinese and US cultures differ widely in their values, which produces different attitudes and behaviors. This study purports to add to the existent knowledge on the managerial values in the USA and China by empirically comparing and contrasting these values along several dimensions.

Design/methodology/approach - This empirical investigation examines the differences in managerial values between US and Chinese managers through independent sample $t$-tests based on survey responses from 1,741 US and 982 Chinese managers.

Findings - The findings indicate that significant cultural differences exist between the two samples. Results show that US managers are more individualistic than their Chinese counterparts. The managerial values of the US sample are also characterized by lower power distance, uncertainty avoidance, and work ethics than the Chinese sample.

Practical implications - The findings provide support for the conventional wisdom regarding the differences between the US and Chinese cultures.

Originality/value - The large sample sizes in the research study provide strong empirical support to existent theory.
\end{abstract}

Keywords Managers, Globalization, China, Motivation (psychology), United States of America, National cultures

Paper type Research paper

\section{Introduction}

World markets and political systems have undergone significant changes during the last decade, including radical transformations in the former Soviet Union, Eastern Europe, and China. China, one of the fastest growing economies in the world, has become a major trading partner with the USA. China's rich natural sources and huge market potential has offered great opportunities for a greater trade volume between the two countries. However, as noted by Shenkar and Ronen (1987a, b), trading with Chinese involves major obstacles. The Chinese and US cultures differ widely in their values, which produces different attitudes and behaviors. This study seeks to examine the differences in managerial values between US and Chinese managers.

Knowledge of these cultural differences would be of great interest for international comparative management (Luthans et al., 1993). If cultural values differ significantly between these two nations, then their respective management styles are also likely to in China

Vol. 2 No. 3, 2007

pp. $212-224$

(C) Emerald Group Publishing Limited 1746-8779

DOI $10.1108 / 17468770710825151$ 
differ (Banai and Katsounotos, 1993). Knowledge of national cultures has been seen as a prerequisite to the effective entry into new markets. It is also a prerequisite to the establishment of effective human resource programs in different cultural contexts (Morden, 1995). Therefore, it is vital to examine the cross-cultural differences in values held by the managers of the two countries.

Though China was not included in Hofstede's (1980) study, other Chinese-populated countries such as Taiwan, Singapore, and Hong Kong were included in that study. A lot of inferences have been made about the Chinese based on these three countries. Such conclusions may be very misleading because these countries present different political, economical, and demographical characteristics compared to China. While some have argued that these three countries resemble China (Hofstede, 1980; Johns and Xie, 1998), others have suggested that differences might exist (Shenkar and Ronen, 1987a, b). First of all, the People's Republic of China is still a developing nation, with per capita income far below the other three Chinese countries. In addition, while those other countries have had extensive rapport with the rest of the world, China has been isolated for many years until recently (Shenkar and Ronen, 1987a, b). It has been argued that despite the recent development, many of which are limited to the special trade zones, China still carries attributes that challenges Western assumptions on management and organization (Laaksonen, 1984; Shenkar and Ronen, 1987a, b). Thus, it is likely that cultural values may be quite different than the Chinese in Taiwan, Hong Kong, and Singapore. Therefore, the focus on China as a unit of analysis sharpened subsequent to Hofstede (1980), with Hofstede himself globalizing his research scope to include China and 55 other nations across the globe (www.Geert-Hofstede.com; Hofstede, 2001).

Given its raising economic dominance, China has been a subject of research study to understand the roots of its economic success in terms of a cultural explanation (Ralston et al., 1996, 1999; Peng and Shekshnia, 2001; Chen, 2002; Liu et al., 2002; Holliday and Wong, 2003; Fan and Zigang, 2004; Shafer et al., 2007). Within this research stream focused on China is a distinct thread of comparative analyses that attempts to surface the distinctive features of the Chinese culture vis-à-vis other cultures. These comparative studies provide more insightful analyses suggesting potential sources of comparative advantage stemming from specific differences across cultures. Notable comparative research studies include www.Geert-Hofstede.com, Ralston et al. (1993a, b, 1997, 2006), Hofstede (2001), Tan (2002), Egri and Ralston (2004), Spector et al. (2004) and Shafer et al. (2007). Despite the abundance of cumulative knowledge with a research focus on China, McSweeney (2002) suggests that it is a triumph of faith rather than unequivocal theory borne out of analytical rigor in empirical research, and calls for more rigorous research on the subject using larger samples. This paper adds to this comparative literature stream with additional empirical evidence from large samples using a broadened research perspective. Specifically, the purpose of this paper is to study the differences in managerial values between the US and Chinese managers based on Hofstede's (1980) four dimensions and on Buchholz's (1978) work-ethics dimension.

\section{Theoretical background}

Cross-cultural research has been based on various assumptions about the association between sociocultural, economic, organizational, and personality factors and
Comparative analysis of managerial values

213 
JTMC 2,3

214 values (Elenkov, 1996). There is a strong argument in favor of studying national cultures with the purpose of understanding managerial values and behaviors (Hofstede, 1980, 1991). The underlying assumption of cross-cultural research focusing on international management issues has been that every society creates its distinct values. Societies create their own cultures and organizational systems compatible with that culture (Ralston et al., 1993a, b).

The study of cultures and work-related cultural values has gained a great deal of attention since Hofstede published his seminal work in 1980. In his work, Hofstede argued that work-related values of national cultures could be easily understood or summarized along four cultural dimensions, which are known as power distance, individualism-collectivism, masculinity, and uncertainty avoidance. More specifically, he found considerable cultural differences among different nationalities along these four cultural dimensions. As two decades have passed since Hofstede's work, the topic of cross-cultural research has remained an area that has been widely studied (Ralston et al., 1996, 1999; Peng and Shekshnia, 2001; Chen, 2002; Liu et al., 2002; Holliday and Wong, 2003; Fernandez et al., 1997).

Despite its widespread familiarity and influence, Hofstede's work has been extensively criticized. One reason is that he used the employees of a single large multinational company to represent the cultures of different nationalities. It is clear that such a sample, no matter how large, may not be representative of the respective countries' national cultures.

Studying cultures is a vital part of understanding the behaviors of individuals in organizations. This is especially important for international or multinational companies, since they have to deal with employees in different countries with different cultures. Many administrative problems faced by international companies stem from an incongruence between management's underlying core values (organizational culture) and the values central to the host setting (national culture). For example, a multinational company may have a rather bureaucratical and/or top-down administrative system. This type of a formal structure may work well in a national culture that scores high on power distance, but it may adversely affect the functioning of the organization in a country where the power distance tends to be small or smaller.

The relationship between cultures and the functioning of organizations has been a recurring theme in the social sciences for over 50 years. Sociologists, social anthropologists, and social psychologist have tended to look at culture as an integral feature of society (Weber, 1930; Mead, 1934). Culture has also been studied extensively at the organizational level from the perspective of its relationship to the functioning of the firm (Wilkins and Ouchi, 1983; Van Maanen and Schein, 1979; Schwartz, 1992).

Hofstede's (1980) research on culture is probably the most widely recognized in this field. He has helped to stimulate a great deal of research and discussion about culture. He defined culture as "the collective programming of the mind which distinguishes the member of one human group from another" (Hofstede, 1984). By using questionnaires from more than 116,000 IBM employees.

Power distance is "the extent to which a society accepts the fact that power is distributed unequally" (Hofstede, 1980, p. 45). Individualism-collectivism:

... implies a loosely knit social framework in which people are supposed to take care of themselves and of their immediate families only, while collectivism is characterized by a tight 
social framework in which people distinguish between in-groups and out-groups (relatives, organizations, etc.) to look after them, and in exchange for that they feel absolute loyalty to it (p. 45).

Masculinity-femininity, or what Hofstede initially called just "Masculinity," is concerned with the extent to which the dominant values in a society are "masculine," i.e. assertiveness, the acquisition of money and things, and not caring for others, the quality of life, or people (p. 46). Uncertainty avoidance:

... indicates the extent to which individuals in a society feel threatened by uncertain and ambiguous situations and try to avoid these situations by providing greater career stability, establishing more formal rules, not tolerating deviant ideas and behaviors, and believing in absolute truths and the attainment of expertise (p. 45).

These four dimensions were one of the main outcomes of the study that had gathered the data form a huge sample size and from over 40 countries.

Soon after Hofstede (1980) published his research, various researchers pointed out the limitations of Hofstede's work (Goodstein, 1981; Hunt, 1981). As mentioned before, the sample was taken from IBM, a large but a single organization. It is known that cross-cultural research has presented problems in data collection (Adler, 1993). As such, much research in this area has often been done through a single multinational corporation (MNCs) (Goodstein, 1981). As a result, the employees that have been surveyed may not be reflective enough of their countries, as it is the case in Hofstede's study. Because of the various methodological problems, and also due the importance of Hofstde's study, many researchers have conducted cross-cultural studies on their own (Nicholson, 1991; Schein, 1985).

In a study of 12 countries, Bass and Burger (1979) found that more often than not, national cultures made a considerable difference in managers' goals, preferences for taking risks, pragmatism, emotional stability, and leadership style. Another study found that managers in different countries differed significantly from one another in the extent to which they endorsed participation, and in their belief about the capacity of their subordinates to participate effectively (Haire et al., 1966). Similar conclusions were drawn in a more recent study, which found that the values, beliefs, norms, and ideals are captured in a country's culture and affected the leadership behavior, goal, and strategies of organizations (Adler et al., 1989).

\section{Research hypotheses}

The power distance dimension refers to the extent to which status differences between people in organizations are accepted and institutionalized. A high-power distance in organizations indicates that a strict hierarchy exists and power is centralized. Thus, the concept of power distance is important in identifying differences across national cultures (Hofstede and Bond, 1984). The culture of traditional China encompasses diverse and competing philosophies, including Taoism, Buddhism, Legalism, and other less pervasive traditions (Shenkar and Ronen, 1987a, b). Nevertheless, Confucianism is considered as the basis for Chinese values. One of the principles within this cultural framework has been the emphasis on hierarchy, which emphasizes that each individual should be conscious of her or his position in the social system (Eberhard, 1971). Despite the attack on this principle by the Maoist ideology during the cultural revolution, it is still considered to be widely accepted (Laaksonen, 1984). The recent study by
Comparative analysis of managerial values 
JTMC 2,3

\section{6}

Fernandez et al. (1997) has placed China among the countries with high-power distance. In comparison, prior research has shown that the US culture is characterized by low- to moderate-power distance (Hofstede, 1980):

H1. Chinese managers will score higher than US managers in power distance.

Individualism is reflected in the way people live together (Triandis, 1980). Harmony, which reflects an aspiration toward a conflict-free, group-based system of social relations, is still a significant value that characterizes the Chinese society (Shenkar and Ronen, 1987a, b). Similarly, Johns and Xie (1998) have argued that in spite of the exclusion of China from Hofsetde's study, it resembles very much the other Chinese populated countries in collectivism. In contrast, Americans have been found to place high value on individualism, personal freedom of choice, and individual initiative (Hofstede, 1980, 1991). Because national culture is believed to have a strong effect on personal values, it can be expected that Americans would demonstrate higher individual values:

H2. US managers will score higher than Chinese managers on individualism.

Masculinity is an assertive or competitive orientation of thinking and acting. The Chinese preference for restrained, moderate behavior suggests that one should avoid overtly aggressive behavior (Shenkar and Ronen, 1987a, b). In Hofstede's (1980) study, the other three Chinese countries scored slightly lower on the masculinity dimension than the US. Given China's more egalitarian and socialistic political system, one could expect that China would even score lower than the Taiwan, Singapore, and Hong Kong on this dimension. The USA has been placed among the countries with moderate to high masculinity (Hofstede, 1980). As noted by Elenkov (1996), the US is commonly associated with a pronounced orientation toward interpersonal competition in almost all aspects of life:

H3. US managers will score higher than the Chinese managers in masculinity.

Uncertainty avoidance shows the extent to which individuals in a society feel threatened by uncertainties (Hofstede, 1980). American executives were found to take more risks, and to believe more strongly in self-determination than many other countries (Hofstede, 1980). In contrast, people in China would seem to prefer harmony, and avoid uncertainties. However, Hofstede (1980) found conflicting results in his study for the three different Chinese countries. Whereas Taiwan scored higher than the USA, Singapore and Hong Kong obtained lower scores than the US on this dimension. Assuming that the political system in China has imposed values on the citizens of that country that would undermine behaviors such as risk taking, it would be expected that uncertainty avoidance would be higher in China than in USA:

H4. Chinese managers will score higher than the US managers in uncertainty avoidance.

Work-ethic means that work is good in itself and bestows dignity on a person (Dickson and Buchholz, 1979). According to Dickson and Buchholz (1979, p. 45):

By working hard a person can overcome every obstacle that life presents and make his own way in the world. Success is thus directly linked to one's own efforts and the material wealth a person accumulates is a measure of how much effort he/she has expended. 
The US has been traditionally associated with high work ethics. China, in contrast, has been considered a formidable challenge in this regard (Miller, 1995). Others have argued that the Chinese consider work as clearly more important than leisure and as contributing to family welfare (Shenkar and Ronen, 1987a, b). There have been studies about Chinese in Hong Kong, which reported strong emphasis on intensive work and on duty (Shenkar and Ronen, 1987a, b). On the other hand, there have been arguments suggesting that the traditionally high work-ethics in the US has been on a declining trend (Buchholz, 1978). In fact, Buchholz (1978) found low scores of work ethics across all organizational groups in the USA:

H5. Chinese managers will score higher than US managers on work-ethics.

\section{Data, methodology and analysis Sample}

The data that used for this study is part of a much larger sample, which was collected by a comprehensive team of researchers from nine different countries on four different continents. The sampling design aimed "to create a means by which broad-scale cross-cultural research could be conducted" (Fernandez et al., 1997, p. 45). The data was collected over a period of about two years (1989-1991). The sample for the USA and China consisted of 1,819 and 982 respondents, respectively. Missing cases for the Chinese sample were listwise deleted, resulting in a sample with 1,741 usable responses. Although it is often desirable to have even larger sample sizes in cross-cultural research, the current sample sizes for both countries are deemed to be sufficient.

The demographic characteristics of the sample was made up of individuals who were young, well educated, unmarried, had diverse work experience (e.g. variety of professions, experience in different industries, and public versus private institutions, etc.) and split between males and females about equally.

\section{Measures}

The survey instrument was developed using cultural values modeled after the works by Hofstede (1980), Buchholz (1976), and Dorfman and Howell (1988). The dependent variables are uncertainty avoidance, power distance, individualism/collectivism, masculinity, and work ethics. With the exception of demographic variables, the dependent variables (Hofstede dimensions) were measured with multi-item scales developed by Dorfman and Howell (1988). All items were measured on a five-point Likert-type scale ranging from strong disagreement (1) to strong agreement (5). The demographic variables were measured on a single item basis. The scales were translated to Chinese, and then back-translated into English by different bilingual translators, and the variances were resolved to ensure equivalency between the versions. Country of origin, or nationality represents the independent variable, which are the USA and China. Using country as the independent variable has obviously some disadvantages since this may lead overgeneralization of cultural values for the members of those countries. It is obvious that there might be always large differences among people within countries. However, it also has been noted that managers in MNCs can better understand similarities and differences in culture on a country basis due to its simplicity (Ronen and Shenkar, 1985).
Comparative analysis of managerial values 


\section{JTMC 2,3}

218

\section{Sample validity}

Although, we surveyed a very broad population of respondents in USA and China, when a mail survey is conducted there is no way to ensure that 100 percent of those will respond to the questionnaire. Therefore, it was necessary to conduct statistical tests to determine the extent to which respondents were representative of the population and the data are reliable. The questionnaire was sent again with a reminder to all non-respondents after the first round of responses were received. Complete responses from the second wave were included in the sample for analysis. $T$-tests indicated that there is no statistically significant difference in age, gender, marital status, education level and experience between the early respondents (the first wave) and late respondents (the second wave). Since, late respondents could be expected to be more similar to non-respondents than earlier respondents (Kanuk and Berenson, 1975; Oppenheim, 1966), these tests provide no reason to suspect bias in the sample. Hence, the samples are deemed to be a valid representation of the populations they are drawn from.

\section{Reliability of measures}

As stated earlier, we used a questionnaire that was derived from the cultural values modeled in the works by Hofstede (1980), Buchholz (1976), and Dorfman and Howell (1988). This gave us the confidence that there was content validity for the measures used. However, the reliability of a construct refers to the stability of the construct (i.e. repeatability of the measurement) (Nunnaly, 1978). Reliability is a necessary condition for construct measurement. Reliability analysis determines the internal consistency of the sub-items that go to make up the broad research construct. The issue of reliability of the composites may then be evaluated by examining the Cronbach's (1951) $\alpha$ statistic applied to the sub-item scores and the composite construct. Cronbach's $\alpha$ is based on the assumption that the items making a measure are homogenous measures (Allen and Yen, 1979), that is, the items used to measure a construct tap the same set of responses. The Cronbach's $\alpha$ for all the five research constructs in this study exceeded 0.7 which make them more rigorous than Hofstede's measures (McSweeney, 2002). Spector et al. (2001, p. 270) investigated the psychometric properties of Hofstede's measures and concluded that the internal consistencies tended to be even failing to meet the liberal criterion of 0.6 value for Cronbach's $\alpha$ (Hair et al., 1998). Thus, we deem the data in this study to be reliable measures of the research constructs.

\section{Analysis}

The hypotheses have been tested with the independent-samples $t$-test. Using the independent sample $t$-test to test the hypotheses is considered to be appropriate because the data are obtained from two different populations, which are unrelated to each other. The intended statistical procedure will allow testing for significant differences in means for each hypothesis. Therefore, the $t$-test is considered to be the appropriate procedure.

The results will indicate whether there are significant differences for US and Chinese managers along the five cultural dimensions.

\section{Results}

Results from the statistical analyses conducted show interesting differences along the various cultural dimensions under consideration. Descriptive statistics and 
correlations for the US and Chinese samples are presented in Tables I and II, respectively. The means should be interpreted as such that higher scores indicate higher collectivism, masculinity, power-distance, uncertainty avoidance, and work-ethics. For example, while the Chinese had an average score of 3.17 on collectivism, the US mean was lower at 2.59, indicating higher levels of collectivism in the Chinese sample compared to the US sample. The $t$-test results comparing the various dimension of managerial values between the Chinese and US sample are displayed in Table III.

All of the $t$-scores were obtained assuming equal variances with the exception of the power-distance variable. Levene's Test for equality of variances was not found to be significant for this variable at the 0.05 level. All the other variables were significant. The direction of the relationships between national culture and the dependent variables can be seen in Table III.

As can be seen, the Chinese sample demonstrates higher means than the US sample on all of the cultural dimensions considered. First, managers from China scored significantly higher on collectivism compared to managers from the US. These results

\begin{tabular}{lcccccr}
\hline Variables & Means & SD & 1 & 2 & 3 & 4 \\
\hline 1. Individualism-collectivism & 2.59 & 0.70 & & & & \\
2. Masculinity-femininity & 2.09 & 0.85 & $0.33^{*}$ & & & \\
3. Power-distance & 2.54 & 0.66 & $0.27^{*}$ & $0.38^{*}$ & & \\
4. Uncertainty avoidance & 2.80 & 0.46 & $0.16^{*}$ & $0.09^{*}$ & $0.12^{*}$ & \\
5. Workethics & 2.59 & 0.62 & $0.15^{*}$ & $0.16^{*}$ & $0.25^{*}$ & 0.03
\end{tabular}

Notes: $N=1,741 ;{ }^{*} p<0.01$
Comparative analysis of managerial values

219

\begin{tabular}{|c|c|c|c|c|c|c|c|}
\hline Variables & Means & $\mathrm{SD}$ & 1 & 2 & 3 & 4 & \\
\hline 1. Individualism-collectivism & 3.17 & 0.74 & & & & & \\
\hline 2. Masculinity-femininity & 3.05 & 0.75 & $0.14^{*}$ & & & & \\
\hline 3. Power-distance & 2.90 & 0.66 & $0.25^{*}$ & $0.23^{*}$ & & & \\
\hline 4. Uncertainty avoidance & 2.85 & 0.60 & $0.29 *$ & 0.02 & $0.21^{*}$ & & Table II. \\
\hline 5. Work-ethics & 3.37 & 0.50 & $0.19^{*}$ & $0.21^{*}$ & $0.15^{*}$ & $0.09 *$ & $\begin{array}{l}\text { Descriptive statistics and } \\
\text { correlations for Chinese }\end{array}$ \\
\hline Notes: $N=982 ; * p<0.01$ & & & & & & & managers \\
\hline
\end{tabular}

\begin{tabular}{|c|c|c|c|c|}
\hline Variable & Chinese & USA & $t$-value & \\
\hline Individualism-collectivism & 3.17 & 2.59 & $20.37^{* *}$ & \\
\hline Masculinity-femininity & 3.05 & 2.09 & 29.57 & \\
\hline Power-distance & 2.90 & 2.54 & $13.44^{* *}$ & \\
\hline Uncertainty avoidance & 2.85 & 2.80 & $2.42^{*}$ & Table III. \\
\hline Work-ethics & 3.37 & 2.59 & $33.48^{* *}$ & $\begin{array}{c}\text { Comparative analysis of } \\
\text { the US and Chinese }\end{array}$ \\
\hline Notes: ${ }^{*} p<0.05 ;{ }^{* *} p<0.001$ & & & & dimensions ( $t$-tests) \\
\hline
\end{tabular}


JTMC 2,3 lend support for H1. No support was found for the H2, that managers from the US would score higher on masculinity than the Chinese managers. Although a statistical difference exists between the two groups, the difference was in the opposite direction from what was hypothesized. Support was also found for H3. This indicates that power distance was significantly higher for Chinese managers than for US managers. Further, uncertainty avoidance for the Chinese sample was found to be slightly higher than the US sample, giving support for H4. Finally, as suggested in H5, Chinese managers were found to have higher work-ethics compared to US managers. The associated $t$-values illustrated in Table III show significant mean differences for all the variables. Thus, $H 1, H 2, H 4$, and $H 5$ were supported, while $H 3$ was not supported.

\section{Discussion and conclusion}

The focus of this paper was on understanding the difference in managerial values between US and Chinese managers on various cultural dimensions. More specifically, the study investigated the differences in power-distance, individualism-collectivism, masculinity, uncertainty avoidance, and work ethics between the two countries. Thus, the primary contribution of this paper is the development of further empirical evidence to support the argument that significant cultural differences exist. Understanding the differences in values of Americans and Chinese is essential, since culture influences the way managers behave. If matching a cultural system with organizational structure enhances organizational effectiveness, then it is natural to assume that a harmony between managerial behavior and cultural values should lead to increased effectiveness for the growing number of business partnerships between Chinese and US joint-ventures.

This comparative analysis of cultural values in the USA and China reveals that significant cultural differences exist between the two countries. Americans are more individualistic than the Chinese. The culture in the US is also characterized by lower power distance and uncertainty avoidance than the Chinese culture. In addition, work ethics was found to be higher in China. These results are compatible with the findings of prior research. For example, Franke et al. (1991) concluded that people in richer nations, in terms of GNP per capita, tend to accept less inequality in organizations (have lower power distance), focus more on the individual (higher individualism), and are more open to uncertainty (lower uncertainty avoidance) than people in less developed countries. On the other hand, the higher average of the Chinese on masculinity seems to demonstrate that assertive and competitive thinking is not only a characteristic of the US, both also of the Chinese.

This study has also its limitations. First of all, although a rather large sample was used, it should be noted that both the US and China are huge countries. The group of respondents cannot be considered a perfect representation of all the people in both countries. In addition, the use of Western instruments in an Asian country may still lack the face validity despite the efforts made in this regard. Therefore, caution should be used in making inferences. Despite these limitations, our findings point out the importance of cultural context and, in particular, that we cannot assume the findings based on interactions within Western cultural contexts will predictably apply to managerial behaviors in China. In sum, this study provides managers with some evidence regarding how to understand and differentiate managerial values and behaviors across the USA and China. In conclusion we argue that, possibly, managerial 
values, as much as any other firm level decision, are responsible for the observed successes and failures. What are standard and well accepted measures in managerial behavior (for example, in technology management, R\&D management, project management or innovation management) may not necessarily derive from Western exemplars or even be strictly applicable to the Chinese reality. This paper presents evidence that differences in managerial values can explain differences in managerial behaviors.

\section{References}

Adler, N.J. (1993), "Competitive frontiers: women managers in the triad", International Studies of Management and Organization, Vol. 23 No. 2, pp. 3-23.

Adler, N.J., Campbell, N. and Laurent, A. (1989), "In search of appropriate methodology: from outside the People's Republic of China looking in", Journal of International Business Studies, Vol. 20 No. 1, pp. 61-74.

Allen, M. and Yen, W. (1979), Introduction to Measurement Theory, Brooks/Cole Publishing Company, Monterey, CA.

Banai, M. and Katsounotos, P. (1993), "Participative management in Cyprus", International Studies of Management \& Organization, Vol. 23 No. 4, pp. 19-34.

Bass, B.M. and Burger, P.C. (1979), Assessment of Managers: An International Comparison, The Free Press, New York, NY.

Buchholz, R.A. (1976), "Measurement of beliefs", Human Relations, Vol. 29, pp. 1177-88.

Buchholz, R.A. (1978), "The work ethic reconsidered", Industrial \& Labor Relations Review, Vol. 31 No. 4, pp. 450-9.

Chen, A. (2002), "The structure of Chinese industry and the impact of China's WTO entry", Comparative Economic Studies, Vol. 44 No. 1, pp. 72-98.

Cronbach, L. (1951), "Coefficient alpha and internal structure of tests", Psychometrics, Vol. 16, pp. 297-334.

Dickson, J.W. and Buchholz, R.A. (1979), "Managerial beliefs about work in Scotland and the USA", The Journal of Management Studies, Vol. 5, pp. 80-101.

Dorfman, P.W. and Howell, J.P. (1988), "Dimensions of national culture and effective leadership patterns: Hofstede revisited", in Farmer, R.N. and McGoun, E.G. (Eds), Advances in International Comparative Management, JAI Press, Greenwich, CT, pp. 127-50.

Eberhard, W. (1971), Moral and Social Values of the Chinese-collected Essays, Chinese Materials and Research Aids Service Center, Washington, DC.

Egri, C.P. and Ralston, D.A. (2004), "Generation cohorts and personal values: a comparison and China and the U.S.”, Organization Science, Vol. 15, pp. 210-20.

Elenkov, D.S. (1996), "Differences and similarities in managerial values between U.S. and Russian managers", International Studies of Management \& Organization, Vol. 27 No. 2, pp. 85-106.

Fan, P. and Zigang, Z. (2004), "Cross-cultural challenges when doing business in China", Singapore Management Review, Vol. 26 No. 1, pp. 81-90.

Fernandez, D.R., Carlson, D.S., Stepina, L.P. and Nicholson, J.D. (1997), "Hofstede's country classification 25 years later”, The Journal of Social Psychology, Vol. 137 No. 1, pp. 43-54.

Franke, R.H., Hofstede, G. and Bond, M.H. (1991), "Cultural roots of economic performance: a research note", Strategic Management Journal, Vol. 12, pp. 165-73.
Comparative analysis of managerial values

221 
JTMC 2,3
Goodstein, L. (1981), "Commentary: do American theories apply abroad? American business values and cultural imperialism", Organizational Dynamics, Summer, pp. 49-54.

Hair, J.F. Jr, Anderson, R.E., Tatham, R.L. and Black, W.C. (1998), Multivariate Data Analysis, Prentice Hall, Inc., Englewood Cliffs, NJ.

Haire, M., Ghiselli, E.G. and Porter, L.W. (1966), Managerial Thinking: An International Study, Wiley, New York, NY.

Hofstede, G. (1980), Culture's Consequences: International Differences in Work-related Values, Sage, Beverly Hills, CA.

Hofstede, G. (1984), Culture's Consequences: International Differences in Work Related Values, Sage, Thousand Oaks, CA.

Hofstede, G. (1991), Cultures and Organizations: Software of the Mind, McGraw-Hill, London.

Hofstede, G. (2001), Culture's Consequences: Comparing Values, Behaviors, Institutions and Organizations across Nations, 2nd ed., Sage, Thousand Oaks, CA.

Hofstede, G. and Bond, M. (1984), "Hofstede's culture dimensions: an independent validation using Rokeach's value survey”, Journal of Cross-Cultural Psychology, Vol. 15, pp. 417-33.

Holliday, I. and Wong, L. (2003), "Social policy under one country and two systems: institutional dynamics in China and Hong Kong since 1997", Public Administration Review, Vol. 63 No. 3, pp. 269-82.

Hunt, J. (1981), "Commentary: do American theories apply abroad? Applying American behavioral science: some cross-cultural problems", Organizational Dynamics, Summer, pp. 55-62.

Johns, G. and Xie, J.L. (1998), "Perceptions of absence from work: People's Republic of China versus Canada”, Journal of Applied Psychology, Vol. 83 No. 4, pp. 515-30.

Kanuk, L. and Berenson, C. (1975), "Mail surveys and response rates: a literature review", Journal of Marketing Research, Vol. 22, pp. 440-53.

Laaksonen, O. (1984), "The management and power structure of Chinese enterprises during and after the cultural revolution: with empirical data comparing Chinese and European enterprises", Organization Studies, Vol. 5 No. 1, pp. 1-21.

Liu, L.A., Friedman, R.A. and Chi, S. (2002), "Negotiating in different cultures: are Western personality dimensions relevant in Chinese culture?", paper presented at IACM 15th Annual Conference, available at SSRN: http://ssrn.com/abstract $=305202$

Luthans, F., Welsh, D. and Rosenkrantz, S.A. (1993), "What do Russian managers really do? An observational study with comparisons to U.S. managers", Journal of International Business Studies, Vol. 24 No. 4, pp. 741-61.

McSweeney, B. (2002), "Hofstede's model of national cultural differences and their consequences: a triumph of faith - a failure of analysis", Human Relations, Vol. 55 No. 1, pp. 89-118.

Mead, G.H. (1934), Mind, Self and Society, University of Chicago Press, Chicago, IL.

Miller, W.H. (1995), "Managing in China”, Industry Week, Vol. 244 No. 14, pp. 20-6.

Morden, T. (1995), "International culture and management", Management Science, Vol. 33 No. 2, pp. 16-21.

Nicholson, J.D. (1991), "The relationship between cultural values, work beliefs, and attitudes towards socioeconomic issues: a cross-cultural study", $\mathrm{PhD}$ dissertation, Florida State University College of Business, Tallahassee, FL.

Nunnaly, J.C. (1978), Psychometric Theory, McGraw-Hill, New York, NY.

Oppenheim, A.N. (1966), Questionnaire Design and Attitude Measurement, Basic Books, New York, NY. 
Peng, M.W. and Shekshnia, S.V. (2001), "How entrepreneurs create wealth in transitional economies”, Academy of Management Executive, Vol. 15 No. 1, pp. 95-110.

Ralston, D.A., Gustafson, D.J., Cheung, F. and Terpstra, R.H. (1993b), "Differences in managerial values: a study of U.S., Hong Kong and PRC managers", Journal of International Business Studies, Vol. 24, pp. 249-75.

Ralston, D.A., Gustafson, D.J., Terpstra, R.H. and Holt, D.H. (1993a), "The impact of managerial values on decision-making behaviour: a comparison of the United States and Hong Kong", Asia Pacific Journal of Management, Vol. 10 No. 1, pp. 21-37.

Ralston, D.A., Holt, D.A., Terpstra, R.H. and Yu, K. (1997), "The impact of national culture and economic ideology on managerial work values: a study of the United States, Russia, Japan and China”, Journal of International Business Studies, Vol. 28, pp. 177-208.

Ralston, D.A., Yu, K., Wang, X., Terpstra, R.H. and He, W. (1996), "The cosmopolitan Chinese manager: findings of a study on managerial values across the six regions of China", Journal of International Management, Vol. 2, pp. 79-109.

Ralston, D.A., Egri, C.P., Stewart, S., Terpstra, R.H. and Yu, K. (1999), "Doing business in 21st century with the new generation of Chinese manager: a study of generational shifts in work values in China”, Journal of International Business Studies, Vol. 30, pp. 415-28.

Ralston, D.A., Pounder, J., Lo, C.W.H., Wong, Y., Egri, C.P. and Stauffer, J. (2006), "Stability and change in managerial work values: a longitudinal study of China, Hong Kong and the U.S.", Management and Organization Review, Vol. 2 No. 1, pp. 67-94.

Ronen, S. and Shenkar, O. (1985), "Clustering countries on attitudinal dimensions: a review and synthesis", Academy of Management Review, Vol. 10, pp. 435-54.

Schein, E. (1985), Organizational Culture and Leadership, Jossey-Bass, San Francisco, CA.

Schwartz, S.H. (1992), "Universals in the content and structure of values: theoretical advances and empirical tests in 20 countries", in Zanna, M.P. (Ed.), Advances in Experimental Social Psychology, Academic Press, San Diego, CA.

Shafer, W.E., Fukukawa, K. and Lee, G.M. (2007), "Values and the perceived importance of ethics and social responsibility: the U.S. versus China”, Journal of Business Ethics, Vol. 70 No. 1, pp. 265-84.

Shenkar, O. and Ronen, S. (1987a), "The cultural context of negotiations: the implications of Chinese interpersonal norms", Journal of Applied Behavioral Science, Vol. 23 No. 2, pp. 263-75.

Shenkar, O. and Ronen, S. (1987b), "Structure and importance of work goals among managers in the People's Republic of China", Academy of Management Journal, Vol. 30 No. 3, pp. 564-76.

Spector, P.E., Cooper, C.L. and Spark, L. (2001), "An international study of psychometric properties of Hofstede value survey module 1994: a comparison of individual and country/province level results", Applied Psychology, Vol. 50 No. 2, pp. 269-81.

Spector, P.E., Sanchez, J.I., Siu, O.L., Salgado, J. and Ma, J. (2004), "Eastern and western control beliefs at work: an investigation of secondary control, socioinstrumental control, and work locus of control in China and the US", Applied Psychology, Vol. 53 No. 1, pp. 38-50.

Tan, B. (2002), "The impact of national environment on managerial value systems: a comparative study of Chinese managers in the United States, Singapore and the People's Republic of China”, Management International Review, Vol. 42 No. 4, pp. 473-86.

Triandis, H.C. (1980), "Cross-cultural studies of attitudes and beliefs", in Triandis, H.C. and Brislin, R.W. (Eds), Cross-Cultural Psychology, Allyn and Bacon, Boston, MA, pp. 281-334, available at: www.geert-hofstede.com/hofstede_china.shtml 
JTMC 2,3

\section{4}

Van Maanen, J. and Schein, E.H. (1979), "Toward of theory of organizational socialization", Research in Organizational Behavior, Vol. 1, pp. 209-64.

Weber, M. (1930), The Protestant Ethic and the Spirit of Capitalism, Routledge, London.

Wilkins, A.L. and Ouchi, W.G. (1983), "Efficient cultures: exploring the relationship between culture and organizational performance", Administrative Science Quarterly, Vol. 28 No. 3, pp. $468-81$.

\section{Further reading}

Wu, F.W. (1982), "The political risk of foreign direct investment in post-Mao China: a preliminary assessment”, Management International Review, Vol. 22 No. 1, pp. 13-25.

\section{About the authors}

Ravi Chinta has a $\mathrm{PhD}$ in Strategic Management from University of Pittsburgh. He teaches Strategy and Entrepreneurship courses. He has 20 years experience in industry and worked at companies such as IBM, LexisNexis, Hill-Rom and has over six years venture capital experience. He has published over 20 articles in journals that include Long Range Planning, Academy of Management Executive, Journal of Small Business Management. Ravi Chinta is the corresponding author and can be contacted at: ravichinta@hotmail.com

Nejat Capar, $\mathrm{PhD}$, is an Assistant Professor of Strategic Management at Bilkent University in Ankara, Turkey. He received his $\mathrm{PhD}$ in Strategic Management from the Florida State University in 2003. His primary research interests focus on international management related issues as well as product and international diversification, and how these strategies affect firm performance. E-mail: ncapar@aus.edu

To purchase reprints of this article please e-mail: reprints@emeraldinsight.com Or visit our web site for further details: www.emeraldinsight.com/reprints 